\title{
TENDENCIES OF INNOVATION DEVELOPMENT OF THE RUSSIAN IRON AND STEEL INDUSTRY ON THE BASE OF PATENT ANALYTICS FOR THE LARGEST NATIONAL METALLURGICAL COMPANIES
}

\author{
S. A. Savchenkov ${ }^{1}$, V. Yu. Bazhin 1 , O. Volkova² \\ ${ }^{1}$ St. Petersburg Mining University (St. Petersburg, Russia): \\ 2 TU Bergakademie Freiberg (Freiberg, Germany)
}

\section{E-mail: savchenkov_sa@pers.spmi.ru; bazhin_vyu@pers.spmi.ru; volkova@iest.tu-freiberg.de}

\section{A UTHOR'S I N F \\ S. A. Savchenkov, Cand. Eng., Deputy head of the Patent and License Dept., \\ V. Yu. Bazhin, Dr. Eng., Asso- ciate Prof., Head of the dept. of Automation of Technologi- cal Processes and Production, O. Volkova, Dr. Ing., Prof., Director of the Institute of Iron and Steel Technology}

\section{Key words:}

innovations, patent analytics, steel, invention, intellectual property, iron and steel producers.

\section{A B S T RACT}

Iron and steel industry is one of the industrial branches making substantial input in provision of economic growth in Russian Federation; in this connection, innovation development of the metallurgical industry is rather important. The patent researches, in their turn, allow to get statistical data about the patents that are indicators of technological development and reliable parameter of innovation activity in the industry. The paper is devoted to study of the tendencies of innovation development of the national vertically integrated mining and metallurgical companies in order to reveal technological and innovation leaders and trends in this industry. The paper uses the patent method of technological prediction based on patent researches. The results of analysis of patent documents for the large metallurgical companies (Severstal, Magnitogorsk Iron and Steel Works (MMK), Novolipetsk Iron and Steel Works (NLMK), Metalloinvest Management Company, EVRAZ Group, Mechel) are presented. The rating of Russian patentee companies - leaders in iron and steel industry - is prepared for the period 2000-2020. The legal status of patent documents included in the patent portfolios of the companies is determined. Patent activity of the companies is analyzed during the examined period with differentiation by years. The patent documents registered in Russia during 20 years, as well as the documents of Nippon Steel and JFE Holdings are also analyzed for comparison. The collection for each patentee was obtained and their interest areas (corresponding to the definite classes of International Patent Classification (IPC)) were examined with revealing of the most important IPC subgroups. Activity of authors of the examined companies is investigated in order to find out the leading technological development specialists.

\section{Introduction}

Ferrous metallurgy is one of the basic industrial branches of the national industry, able to provide essential input in Russian Federation (RF) economical growth [1-5]. In 2018 Russia occupied the sixth place in production volume among steel producing countries: its annual volume made $71.7 \mathrm{mln}$ tonnes. The leading companies Severstal, Magnitogorsk Iron and Steel Works (MMK), Novolipetsk Iron and Steel Works (NLMK), Metalloinvest Management Company, EVRAZ Group and Mechel produced totally $64.1 \mathrm{mln}$ tonnes, or $89 \%$ of Russian domestic steel production in 2018. Based on the results of January - August 2019, the Russian companies produced $48.3 \mathrm{mln}$ tonnes of steel, while the volume of delivered metallurgical products increased by $4.6 \%$ in comparison with the same period of $2018[6,7]$.

Development strategy of RF iron and steel industry until 2030 notes that stimulation of rise of the technical level of metallurgical production is a priority task aimed on decrease of resource intensity of production facilities and increase of processing efficiency for raw materials [8]. This strategy correlates with the global development tendency of mining and metallurgical companies [9-20].

It is generally recognized that statistical data about patents can be considered as a reliable factor of industrial innovation activity, thereby use of such data for monitoring of innovation activity and development of new technologies becomes a common practice [21, 22]. Researches of innovation activity in Russia allows to establish the effect of number of patents (including inventions and utility models) on the part of newly developed advanced production technologies; influence of patent activity of the companies on innovation activity in the country in general was proved as well [23]. In this connection, patent documents of the largest national vertically integrated mining and metallurgical companies were analyzed in order to reveal technological innovation leaders and trends in the industry.

\section{Order of the patent search}

The search was conducted through the patentsearching system at the web-portal of the Federal Institute of Industrial Property (FIPS), in the database of inventions and utility models, as well as through the patent-searching system "Yandex patents" over the RU patents. The patentee companies were analyzed, as well as the patentee enterprises incorporated in the examined companies. The following companies and enterprises can be listed here: Severstal (Severstalmetiz, SSM-Tyazhmash, Severstal-proekt, KO VNIIMETMASH (Kolpino affiliate), Vorkutaugol); Magnitogorsk Iron and Steel Works - MMK; Novo- 
lipetsk Iron and Steel Works - NLMK (VIZ-Stal, Altay-koks); Metalloinvest Management Company (OEMK - Oskol Electrometallurgical Plant, Ural Steel, Lebedinsky GOK, Mikhailovsky GOK); EVRAZ Group (EVRAZ NTMK (Nizhny Tagil), EVRAZ ZSMK (Novokuznetsk), Vanady Tula, EVRAZ Ruda, Yuzhkuzbassugol); Mechel (Chelyabinsk Metallurgical Plant, Izhstal, Beloretsk Metallurgical Plant, Urals Stampings Plant, Moscow Coke and Gas Plant).

In all cases the date or patent document priority was used in analysis, if other date was not mentioned evidently. Choice of priority date as the basic measurement for temporary analysis makes it possible to concentrate the research on technological aspects connected with conduction of investigations and developments in the preset area during definite period. The considering and withdrawn patent applications were not included in the analysis when presenting the analytical data. The patents with exclusive rights obtained by the examined companies according to alienation agreements were not included in statistics, too. The statistical data are actual at the date of search (10.04.2020).

\section{Patent analytics}

The prepared rating of the Russian patentee companies that are the leaders in the iron and steel industry was based on the dates of applications that were finalized in patents. This rating during 2000-2020 displayed that maximal number of patents were issued to Magnitogorsk Iron and Steel Works (it has 1009 patents, including 595 inventions (IN) and 414 utility models (UM) in its portfolio) (Fig. 1). The second place is occupied by Severstal having 784 patents, and this company is the leader in inventions with $676 \mathrm{IN}$ patents.

Novolipetsk Iron and Steel Works is located at the third place ( 425 patents), it is followed by EVRAZ ( 317 patents), Metalloinvest (162 patents) and Mechel (75 patents) respectively. The large part of utility models at MMK (41\%) and EVRAZ (42\%) should be noted; it testifies about orientation of these companies on quick obtaining protective documents for technological apparatus. Other examined companies are characterized by reverse situation: number of UM patents is essentially lower than number of IN patents $(10 \%$ for Metalloinvest, 13\% for Severstal, 14\% for Mechel and $24 \%$ for NLMK). It means that these companies are aimed on patenting of complicated technical solutions (methods, apparatus, features of compositions) having the inventing level.

Determination of the legal status of the found patent documents (presented in the patent portfolios of the examined companies) allows to evaluate the interest of the patentees in development within technological area that is defined via relationship of numbers of patents being in force and not being in force. Distribution of the patents according to their legal status made it possible to note that the average total percent of the patents being in

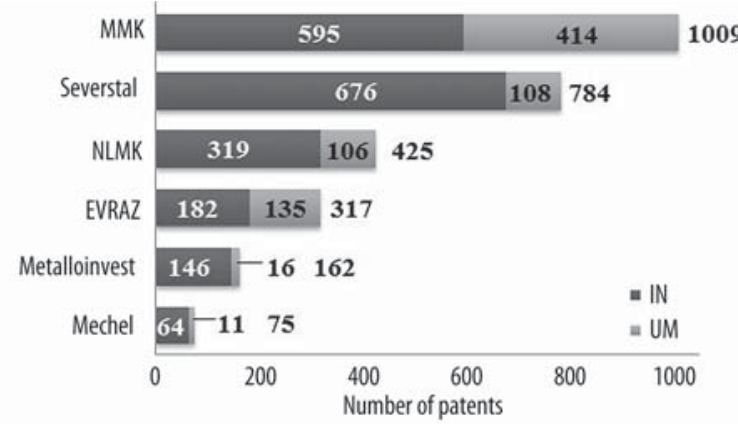

Fig. 1. Rating of Russian patentee companies

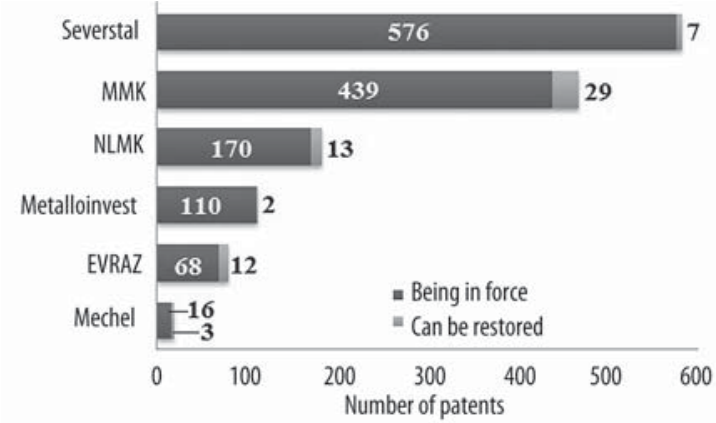

Fig. 2. Legal status of the patents of Russian patentee companies

force is $50 \%$. The obtained rating displays that this situation is not equal for different companies. So, Severstal is a leader in number of the patents being in force for inventions and utility models (85\%), close figures are noted for MMK (74\%) and Metalloinvest (75\%), what means importance of the obtained patents for the a.m. patentees. At the same time NLMK supports $53 \%$ of patents being in force, while EVRAZ and Mechel $27 \%$ and $25 \%$ respectively (Fig. 2 ).

Distribution of number of publications by years is considered as one of the basic analytical presentations during researches of patenting trends in the examined area. It illustrated the dynamics of patent activity of applicants and allows to evaluate the interest of the companies to new developments [26]. The conducted analysis helped to formulate the general understanding about the tendencies of innovation development of the Russian iron and steel industry during 20 years (Fig. 3).

The graph presents the number of applications with issued patents (as a rule, next year after application). It is shown that totally 2,788 patents were obtained by the companies during the examined period. It is noted that dynamics of growth of applications during 20002008 took place, and later the dramatic lowering until the end of the examined period is observed. It displays substantial relationship between the number of applications and the crisis of 2008-2009, because it had serious effect on the state of Russian economy. As a result, the annual growth of the macroeconomic parameters, such as GDP, industrial production, investments in the main capital were decreased essentially [8]. It should be men- 


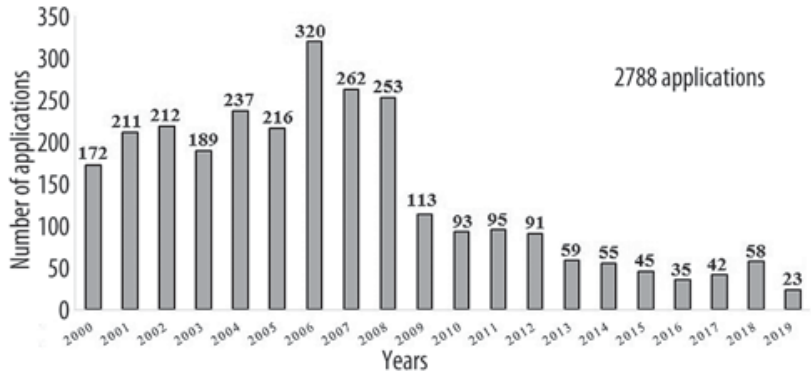

Fig 3. Total number of applications during 2000-2019 (un.)

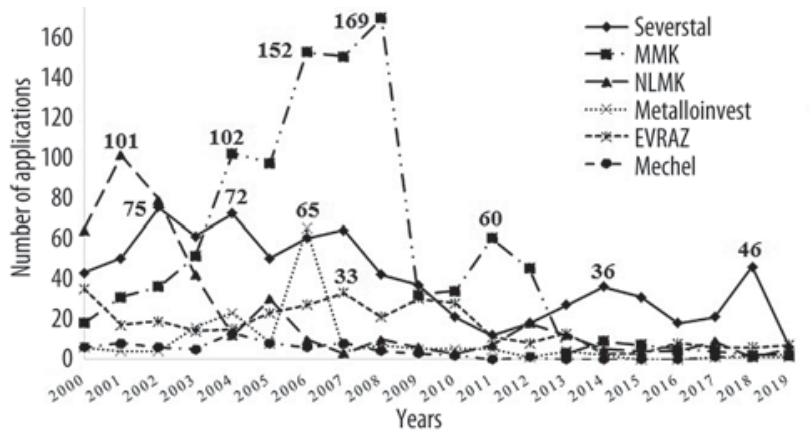

Fig. 4. Number of filed applications during 2000-2019 (un.)

tioned that the amount of applications in 2006 is still the maximal (320 applications). The period 2009-2019 was characterized by sharp lowering of the number of applications, and in the end their number becomes the minimal during the whole examined period (perhaps the 2019 value can increase still, because the applications of this year are still not considered completely). The most typical decrease is presented by 2009 parameters when the number of applications lowered by more than 2 times in comparison with 2008. However, taking into account the general lowering of the number of applications during 2009-2019, we have to note that 2018 is characterized by increase of the number of filing of applications comparing with 2014, 2015, 2016 and 2017.

Fig. 4 displays statistics with distribution by companies and by years of filing of applications. If we shall analyze each company separately, we can see difference with the trend of summarized filing of applications.

Severstal company filed during 201846 applications that consequently finalized in issued patents; it exceeds the values of the each year during 2008-2017. The values of 2002 and 2004 (75 and 72 applications respectively) are the largest for this company. Severstal annually invests in scientific-research and engineering developments (R\&D), and the new, more efficient technologies and products are developing within the frameworks of these R\&D [27]. Table 1 presents innovation parameters of this company, reflecting stable growth of the number of self inventions used at production sites as well as economical effect of their use.

Statistics of Magnitogorsk Iron and Steel Works is characterized by increased patenting activity during 2004-2008, what was connected with development of technical solutions in the field of methods and equip-

\begin{tabular}{|l|c|c|c|c|}
\hline \multicolumn{6}{|l|}{ Table 1. Innovation parameters of Severstal [27] } \\
\hline & 2015 & 2016 & 2017 & 2018 \\
\hline R\&D investing, mln, rub. & 43.7 & 32.7 & 48.3 & 59.9 \\
\hline $\begin{array}{l}\text { Number of new self inventions } \\
\text { used at production sites }\end{array}$ & 88 & 93 & 104 & 178 \\
\hline $\begin{array}{l}\text { Economical effect of used } \\
\text { inventions, mln, rub. }\end{array}$ & 8.78 & 56.23 & 137 & 148 \\
\hline
\end{tabular}

ment for metal processing. Since 2013 we can observe substantial decay of patent activity in comparison with top value of 2008 (169 applications). At present time this steel producer activated its work in the area of inventions and rationalization, and the last mentioned activity was included in the list of priority development directions at MMK since 2015 [28, 29].

Statistics of NLMK displays that the most number of applications with issued patents were filed during 2000-2003 with consequent decrease: 4 applications in 2016, 9 applications in 2017, 1 application in 2018 and 5 applications in 2019. In the end of 2018 the company defined two priority directions for researches and developments: high-tech $\mathrm{Zn}-\mathrm{Al}-\mathrm{Mg}$ coatings and new high-strength steel grades for automotive industry [30].

Metalloinvest had 2006 as the peak year (65 applications with issued patents), and Oskol Electrometallurgical Plant was the patentee of 61 of them. At present time the company includes several departments playing the leading role in modernization and development of production facilities: NPVP TOREKS, GIPROMEZ, Innovation Center JSA Metalloinvest, Scientific and technical steelmaking laboratory [31].

EVRAZ had the peak years in 2007, 2009 and 2010 (33, 30 and 28 applications respectively). During 20162019, 27 applications were filed totally with consequent patent issuing. The company concentrates on fabrication of innovation products (rails, wheels, tubes) for strengthening of its market positions [32].

Statistics of Mechel shows stable filing of relatively small number of applications, the average value during 2008-2019 is 1 application annually. The peak year was 2004 with 13 applications. According to its strategic program, the company is concentrated on production of metallurgical coals, on development of leading positions at the markets of metallurgical products (sections, rails) as well as on increase of the company's part at the markets of high-margin products (special steels and alloys) [33].

Taking into account decline of patent activity for national metallurgical companies during 2009-2019, the authors prepared for comparison the search for the largest foreign steelmaking companies and analyzed their interest to enter the Russian market. Statistics of Nippon Steel Corp. (Japan), which is the patentee of 604 inventions registered in Russia (including 576 inventions being in force) was taken as an example. Such high importance of acting patent documents testifies about serious value of issued patents for this company and its large interest to compete at Russian market with domes- 


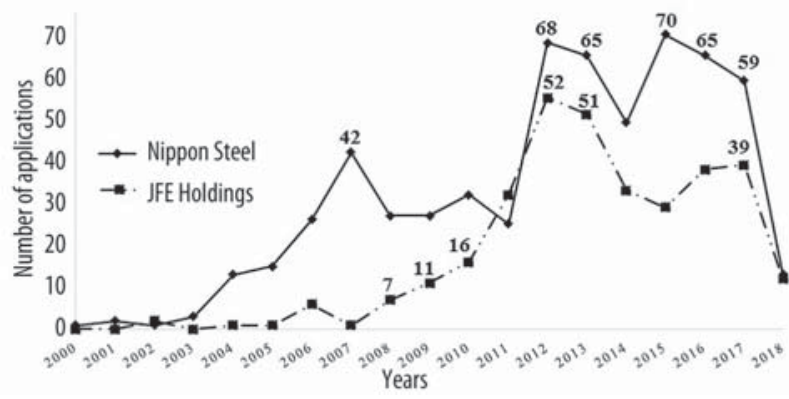

Fig. 5. Number of filed applications during 2000-2018 (un.) physical properties in production of plates or bands via deformation in combination with (or following by) heat treatment. Fig. 6 displays statistics of patents distribution within IPC subclasses for Severstal, MMK, NLMK and EVRAZ. IPC indexes containing the registered patents practically coincide for Severstal and MMK, what testifies that these companies conducted investigations during the a.m. period in the same subject areas.

The most important and actively developing areas of use of technical solutions are described in the table 2 with corresponding IPC indexes.

The patents of Japanese companies Nippon Steel and JFE Holdings that are registered in Russian Federation, are in their turn located in the following most important IPC subclasses: "Alloys of ferrous metals, e.g. alloyed steels" (C22C38/00); "Alloys of ferrous metals, e.g. alloyed steels with $>1.5 \% \mathrm{Mn}$ (mass.)" (C22C38/58); "Heat treatment, e.g. annealing, quenching, tempering of sheet metal" (C21D9/46); "Variation of physical properties in fabrication of products with special electromagnetic properties via deformation in combination with (or following by) heat treatment" (C21D8/12). The most used IPC subclasses for national companies completely coincide with the patent subclasses of Japanese companies Nippon Steel and JFE Holdings, what testifies about competition of foreign and national companies at the Russian market in the field of innovation technologies and products. It should be

tic steel producers. Additionally, dynamics of filing of applications at Nippon Steel differs from dynamics of Russian steelmakers, because increased patenting activity of this Japan company was fixed during 2012-2017; it also confirms intention of Nippon Steel to occupy certain positions at Russian market using innovation technologies and new manufactured products (Fig. 5). This graph also presents statistics of the Japanese company JFE Holdings having exclusive rights for 334 patents and inventions (including 316 being into force). According to these data, the company started active filing of applications in Russia since 2011, what also confirms its interest in fixing the company's positions at Russian markets.

To understand the actual situation and technological direction of patented solutions for national companies, the massif of published patent documentation was analyzed for 10 years, since 01.01.2009 till 10.04.2020. Based on this information, each patentee was analyzed meaning its areas of interests in correspondence with definite classes of International Patent Classification (IPC). Maximal number of found patent documents since 2009 is located in the IPC rubric relating to C21D8/02 subclass, which is devoted to variation of mentioned in this connection that permanent provision of conduction of scientific investigations and protection of intellectual property are strictly required for rise of competition of domestic companies. It will provide technological advantages in several market segments before foreign companies entering the Russian market; otherwise technological retardation is inevitable.

Study of activity of the authors also is very important in patent analysis; it allows to reveal leading technological developers in the examined companies. The presented rating (Fig. 7) includes the authors with more than 20 patents (exclusive rights on these patents belong to the considered companies).

The graph shows that the specialists from Severstal and Magnitogorsk Iron and Steel Works are the leading authors of the patents belonging to these companies. The leading specialists from Severstal P. A. Mishnev, A. M. Korchagin and S. M. Tikhonov had most of their patents and publications in the field of metal processing and rolling [34-40]. MMK leading specialists (S. V. Denisov and P. A. Stekanov) had inventions also relating to rolling [41-44]. It should be mentioned that patent themes of the a.m. inventors corresponds princi- 


\begin{tabular}{|c|c|}
\hline IPC rubric & Description \\
\hline C21D8/02 & $\begin{array}{l}\text { Variation of physical properties in production of plates or bands via deformation in combination with (or following } \\
\text { by) heat treatment }\end{array}$ \\
\hline B21B1/26 & Methods and devices for hot rolling of sheet or section metal \\
\hline $\mathrm{C} 22 \mathrm{C} 38 / 58$ & Alloys of ferrous metals, e.g. alloyed steels with $>1.5 \% \mathrm{Mn}$ (mass.) \\
\hline $\mathrm{C} 22 \mathrm{C} 38 / 00$ & Alloys of ferrous metals, e.g. alloyed steels \\
\hline C21D8/04 & $\begin{array}{l}\text { Variation of physical properties in deep drawing via deformation in combination with (or following by) heat treat- } \\
\text { ment }\end{array}$ \\
\hline C21D9/46 & Heat treatment, e.g. annealing, quenching, tempering of sheet metal \\
\hline $\mathrm{C} 21 \mathrm{C} 7 / 00$ & Processing of molten ferroalloys, e.g. steel \\
\hline $\mathrm{C} 22 \mathrm{C} 38 / 54$ & Alloys of ferrous metals, e.g. alloyed steels with boron \\
\hline $\mathrm{C} 22 \mathrm{C} 38 / 42$ & Alloys of ferrous metals, e.g. alloyed steels with copper \\
\hline $\mathrm{C} 22 \mathrm{C} 38 / 50$ & Alloys of ferrous metals, e.g. alloyed steels with titanium or zirconium \\
\hline C21D8/12 & $\begin{array}{l}\text { Variation of physical properties in fabrication of products with special electromagnetic properties via deformation } \\
\text { in combination with (or following by) heat treatment }\end{array}$ \\
\hline B28B3/20 & Fabrication of shaped products using presses via continuous pressing (extrusion) \\
\hline B29C47/02 & $\begin{array}{l}\text { Extrusion forming including preliminarily formed components or layers, e.g. extrusion forming around inserts or } \\
\text { for coating of components }\end{array}$ \\
\hline C22B1/243 & Preliminary processing of ore or scrap by inorganic substances \\
\hline C21C5/28 & Steel making in basic oxygen converters \\
\hline C21C5/36 & Methods of slag production with special composition \\
\hline C21D9/34 & Heat treatment, e.g. annealing, quenching, tempering of special products (tyres, wheel rims) \\
\hline $\mathrm{C} 22 \mathrm{C} 33 / 04$ & Production of alloys of ferrous metals via melting \\
\hline
\end{tabular}

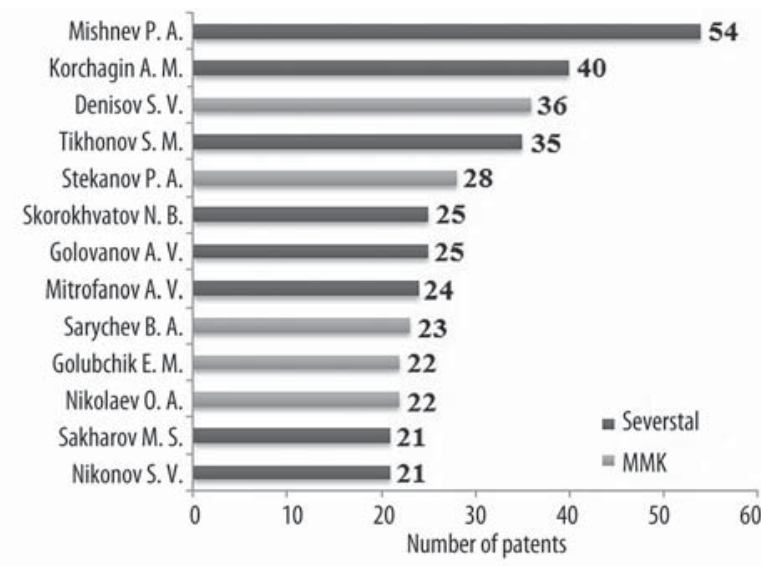

Fig. 7. Rating of inventors with the most large number of publications

pally to general tendency of the industry development [45-49].

\section{Conclusions}

The conducted analysis of patent documents of the largest national vertically integrated mining and metallurgical companies allowed to reveal the technological and innovation leaders in this industry, to find out patenting trends and general dynamics of patent activity as well to define the basic technological segments of patented solutions.
It was established that Severstal and Magnitogorsk Iron and Steel Works, having the most numbers of issued patents for inventions and utility models and high percent of keeping their legal status, are the leaders. Analysis of patent activity during the examined period (since 2000) displayed their growth dynamics of filed applications during 2000-2008 and then dramatic lowering till the end of the examined period, showing essential relationship of the number of filed applications from the crisis 2008-2009. The period 2009-2019 was noted by severe decrease of the number of filed applications (with consequent patent issuing), and their number becomes the minimal during the whole period. The most typical lowering was noted in 2009 , when the number of applications decreased more than by 2 times in comparison with 2008. The patent activity of Japanese companies Nippon Steel Corp. and JFE Holdings testifies in its turn about attractiveness of the internal Russian market for putting into practice of innovation technologies and manufacture of the new products.

The most part of found patent documents since 2009 is concentrated in the following IPC rubrics from Cd1D8/02 subclass that describes variation of physical properties in fabrication of plates and bands (in rolling production). Another widely used IPC subclasses are "Methods and devices for hot rolling of sheet or section metal" (B21B1/26) and "Alloys of ferrous metals, e.g. alloyed steels with > 1.5\% Mn (mass.)" (C22C38/58). 
Reconsideration of the patent strategies of the companies as well as their policy in the field of intellectual property management can be a result of determination of size and value of patent actives of these companies. It is aimed on increase of efficiency of their activity and release of resources for investing in prospective technologies and developments that were revealed both in Russia and in worldwide during study of patenting tendencies. Use of patent analytics during taking the strategic management solutions is recommended as a basement of innovation business development in the conditions of transition to the digital economics.

\section{REFERENCES}

1. Khramova A. I. Strategic analysis of metallurgical development in Russia. Economics. 2016. No. 12 (21). pp. 56-60.

2. Egorova A. O., Kuznetsov V. P., Sevryukova A. A. RF metallurgical complex: state, tendencies, prospects. Uchenye zapiski KGAVM im. N. E. Baumana. 2015. No. 2 (222). pp. 85-89.

3. Ivanter V. V., Uzyakov M. N., Shokin I. N. Long-term Forecast of Russian Economic Development for 2007-2030: Possible Options. Studies on Russian Economic Development. 2007. Vol. 18. No. 6. pp. 565-592.

4. Tsysov A. S. Functional risk areas at metallurgical enterprises. Vestnik akademii znaniy. 2020. No. 2(37). pp. 360-367.

5. Kazakova N. A., Sivkova A. E., Kogdenko V. G., KuzminaMerlino I. Assessment and forecasting of economic sustainability of Russian metallurgical companies. Chernye Metally. 2020. No. 4. pp. 56-64.

6. The review of iron and steel industry market. Deloit. 2019. pp. 1-24.

7. Löf A., Ericsson M., Löf O. Iron ore market review 2018. CIS Iron and Steel Review. 2019. Vol. 17. pp. 4-9.

8. The Order dated May 5, 2014, No. 839 "On acceptance of the development strategy of the Russian iron and steel industry during 2014-2020 and prospectively until 2030. (https://www. garant.ru/products/ipo/prime/doc/70595824/)

9. Litvinenko V. S., Tsvetkov P. S., Molodtsov K. V. The social and market mechanism of sustainable development of public companies in the mineral resource sector. Eurasian Mining. 2020. No. 1. pp. 36-41.

10. Wu X., Zhao L., Zhang Y., Zhao L., Zheng C., Gao X. Cost and potential of energy conservation and collaborative pollutant reduction in the iron and steel industry in China. Applied energy. 2016. Vol. 184. pp. 171-183.

11. Kondrasheva N. K., Rudko V. A. , Lukonin R. E., Derkunskii I. O. The influence of leaching parameters on the extraction of vanadium from petroleum coke. Petroleum Science and Technology. 2019. Vol. 37. No. 12. pp. 1455-1462.

12. Neuhoff K., Ancygier A., Ponssard J.P., Quirion P., Sabio N., Sartor O. Modernization and innovation in the materials sector: Lessons from steel and cement. DIW Economic Bulletin. 2015. Vol. 5. No. 28/29. pp. 387-395.

13. Aleksandrova T., Aleksandrov A., Nikolaeva N. An Investigation of the Possibility of Extraction of Metals from Heavy Oil. Mineral Processing and Extractive Metallurgy Review. 2017. Vol. 38, Iss. 2. pp. 92-95.
14. Vögele S., Grajewski M., Govorukha K., Rübbelke D. Challenges for the European steel industry: Analysis, possible consequences and impacts on sustainable development. Applied Energy. 2020. Vol. 264. 114633.

15. Yurak V. V., Dushin A. V., Mochalova L. A. Vs sustainable development: scenarios for the future. Journal of Mining Institute. 2020. Vol. 242, Iss. 2. pp. 242-247.

16. Litvinenko V. S. Digital Economy as a Factor in the Technological Development of the Mineral Sector. Natural Resources Research. 2020. Vol. 29, Iss. 3. pp. 1521-1541.

17. Nevskaya M. A., Seleznev S. G. , Masloboev V. A., Klyuchnikova E. M., Makarov D. V. Environmental and business challenges presented by mining and mineral processing waste in the Russian federation. Minerals. 2019. Vol. 9. Iss. 7, No. 445.

18. Nevskaya M. A., Marinina O. A. Challenges and opportunities of state regulation of the innovation process in the Russian mineral resources sector. Academy of Strategic Management Journal. 2017. Vol. 16. Issue Specialissue1. pp.149-159.

19. ElDeeb A. B., Brichkin V. N., Kurtenkov R. V., Bormotov I. S. Extraction of alumina from kaolin by a combination of pyroand hydrometallurgical processes. Applied Clay Science. 2019. Vol. 172. pp. 146-154.

20. Elbendary A. H., Aleksandrova T. N., Nikolaeva N. V. Influence of operating parameters on the flotation of the Khibiny Apatite-Nepheline Deposits. Journal of Materials Research and Technology. 2019. Vol. 8. No. 6. pp. 5080-5090.

21. Arkhipova M. Yu. Karpov E. S. Analysis and simulation of patent activity in Russia and developed foreign countries. RISK: Resursy, informatsiya, snabzhenie, konkurentsiya. 2012. No. 4. pp. 286-293.

22. Savchenkov S. A., Bazhin V. Yu., Vilenskaya A. V. Training of specialists in the field of intellectual property protection and invention at universities for mining engineering. Eurasian Mining. 2018. No. 1. pp. 45-47.

23. Mingaleva $\mathrm{Zh}$. A. Influence of patent activity on innovation development of the national economy. Ekonomika regiona. 2010. No. 4. pp. 71-77.

24. FIIP website information searching system (https://www1. fips.ru/iiss/search.xhtml).

25. Information and patent-searching system "Yandex patents" (https://yandex.ru/patents).

26. Patent landscape «Chemical feeding sources». FIPS. 2019. p. 106.

27. Report on "Severstal" corporate social responsibility and development sustainability. 2018. p. 122.

28. Annual report. Magnitogorsk Iron and Steel Works. 2017. p. 111.

29. Denisov S. V., Shevchenko S. V., Mychak M. N. Activation and promotion of innovation, rationalization and invention activities at Magnitogorsk Iron and Steel Works. Chernye Metally. 2017. No. 6. pp. 69-74.

30. Annual report. NLMK. 2018. p. 261.

31. Annual report. Metalloinvest. 2018. p. 118.

32. Annual report. EVRAZ. 2019. p. 261.

33. Annual report of "Mechel" based on 2018 results. p. 55.

34. Komissarov A. A., Sokolov P. Y., Tikhonov S. M., Sidorova E. P., Mishev P. A., Matrosov M. Y., Kuznetsov D. V. Production of Low-Carbon Steel Sheet for Oil-Industry Pipe. Steel in Translation. 2018. Vol. 48. No. 11. pp. 748-753. 
35. Kolbasnikov N. G., Matveev M. A., Mishnev P. A. Effect of structure factor on high-temperature ductility of pipe steels. Metal Science and Heat Treatment. 2016. Vol. 58. No. 1. pp. 51-57.

36. Kolbasnikov N. G., Mishin V. V., Shishov I. A., Matveev M. A., Korchagin A. M. Surface-crack formation in the manufacture of microalloyed steel pipe. Steel in Translation. 2016. Vol. 46. No. 9. pp. 665-670.

37. Kolbasnikov N. G., Zotov O. G., Matveev M. A., Glukhov P. A., Korchagin A. M. Surface-crack formation in the two-phase region when rolling thick microalloyed-steel sheet. Steel in Translation. 2016. Vol. 46. No. 7. pp. 496-502.

38. Matrosov M. Y., Martynov P. G., Kichkina A. A., Talanov O. P., Korchagin A. M., Sychev O. N., Mikheev V. V. Development of low-carbon steel alloyed with copper for pipeline fittings prepared by hot stamping. Metallurgist. 2016. Vol. 60 . No. 3-4. pp. 413-421.

39. Paderin S. N., Serov G. V., Komissarov A. A., Tikhonov S. M., Kuznetsov D. V. Thermodynamic analysis of the reduction of pipe steel. Steel in Translation. 2017. Vol. 47. No. 1. pp. 60-64.

40. Denisov S. V., Stekanov P. A., Poletskov P. P., Gushchina M. S., Nikitenko O. A. Production of Heavy Plates of Pipe Steel with Increased Strength and Cold Resistance on the 5000 Rolling Mill at PJSC MMK. Steel in Translation. 2019. Vol. 49. No. 4. pp. 271-276.

41. Poletskov P. P., Denisov S. V., Nikitenko O. A., Chukin D. M., Gushchina M. S. Decomposition of Supercooled Austenite in Low-Carbon Pipe Steel. Steel in Translation. 2019. Vol. 49. No. 3. pp. 174-178.
42. Denisov S. V., Mychak M. N., Rolled products of Magnitogorsk iron and steel works conquer Arctics. Chernye Metally. 2017. No.11. p. 27.

43. Salganik V. M., Poletskov P. P., Chikishev D. N., Denisov S. V., Stekanov P. A. Laboratory complex for modeling production operations in the rolling of plates. Metallurgist. 2015. Vol. 58. No. 9-10. pp. 921-925.

44. Urtsev V. N., Kornilov V. L., Shmakov A. V. Formation of the Structural State of a High-Strength Low-Alloy Steel upon Hot Rolling and Controlled Cooling. Physics of Metals and Metallography. 2019. Vol. 120. No. 12. pp. 1233-1241.

45. Milyuts V. G., Tsukanov V. V., Pryakhin E. I., Nikitina L. B. Development of manufacturing technology for high-strength hull steel reducing production cycle and providing highquality sheets. Journal of Mining Institute. 2019. Vol. 239. pp. 536-543.

46. Krimpelstätter K., Maeno I., Bergmann M., Keintzel G. Solutions for production of high strength steels and thin cold rolled strips. Chernye Metally. 2020. No. 4. pp. 22-31.

47. Trushko V. L., Utkov V. A. Development of import substituting technologies for increasing productivity of sintering machines and strength of agglomerates. Journal of Mining Institute. 2016. Vol. 221. pp. 675-680.

48. Burkhardt S. 3D slab and heavy plate control. Chernye Metally. 2020. No. 1. pp. 28-30.

49. Korchunov A. G., Polyakova M. A., Konstantinov D. V., Dabalá M. Mechanical properties of prestressing strands and how they tend to change under thermo-mechanical treatment. CIS Iron and Steel Review. 2019. Vol. 18. pp.14-19.

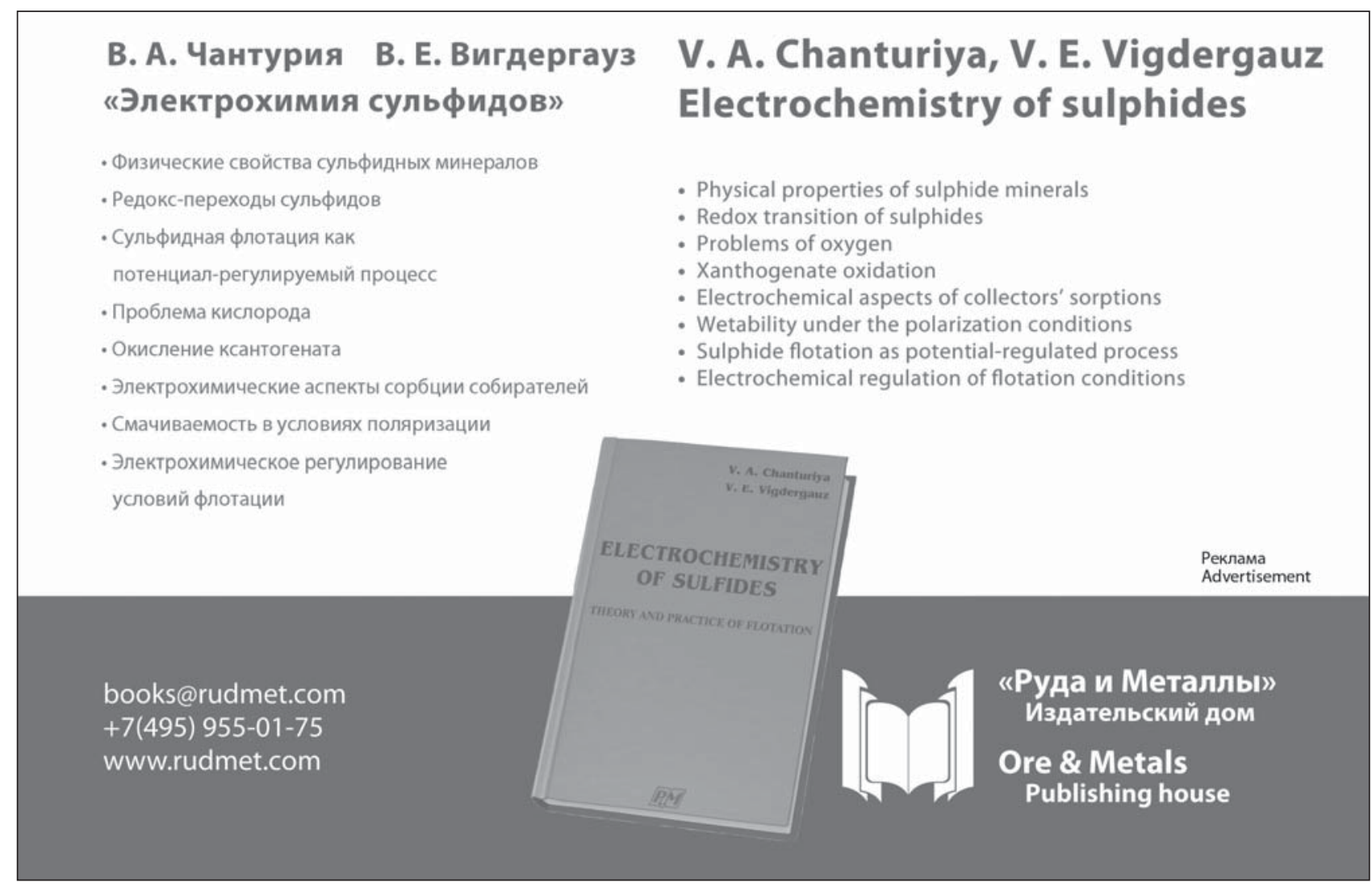

